\title{
Sustainable Design: A Reflection on Progressive Practices
}

\author{
Warren Stiver \\ Professor \& \\ NSERC Chair Environmental Design Engineering \\ School of Engineering, \\ University of Guelph \\ wstiver@uoguelph.ca
}

\begin{abstract}
Sustainable design will ultimately be recognized as synonymous with excellence in engineering design. There are companies and there are communities making considerable progress. Developing more sustainable designs and developing more sustainable communities moves the entire world forward. Our great, grandchildren will view these efforts with awe and with gratitude.

Engineering education has much to learn from progressive practices around the world and much to learn from our students. A significant fraction of our students recognize the importance of sustainability and they hope that their engineering education empowers them to make a difference in the world. Engineering education should aspire to graduate engineers who will lead in sustainable design.

This presentation will reflect on progressive practices in jurisdictions, in companies and in engineering education. The intent is to inspire engineering educators to take advantage of these practices to advance sustainable design within their courses and their engineering program.
\end{abstract}

\section{Introduction}

"Humanity has the ability to make development sustainable. To ensure that it meets the needs of the present without compromising the ability of future generations to meet their own needs"[1]. Although society is believed to have the ability, society has yet to demonstrate that it will choose to do so. It is widely understood that our current practices are far from sustainable.

The world's economy relies on cheap energy that relies on cheap supply of a non-renewable resource. The world's population is forecasted to grow to between 7.96 and 10.5 billion by the year 2050 [2]. Life expectancy in Africa is on the decline [3]. Climate change may lead to a planet that struggles to support life.
The concept of meeting the needs of today without compromising the future seems simple enough. However, translating the concept into reality continues to be a challenge. It has come to be understood that we need to simultaneously consider each of our actions and each of our decisions from economic, social and environmental perspectives. Ignoring any one perspective will preclude success in all three in the long term. In 1994, SustainAbility coined the phrase Triple Bottom Line along with the 3 P's (People, Place and Profit) [4]. The Triple Bottom Line does not imply converting all environmental and social costs in dollar equivalents. The Triple Bottom Line requires a separate accounting of the economic, environment and social balance sheets with sustainable solutions offering a profit in all three accounts.

"What hasn't yet been recognized is that engineering is the sustainability profession" [5]. The recognition may not be there because the engineering profession has yet to deliver on sustainability. Engineering education has yet to embrace sustainability and sustainable design as core to all engineering disciplines.

The objective of this paper and presentation is to motivate engineering educators to raise the bar. Benchmarking against the behaviour of the median jurisdiction, the median company and the median engineering school is a means to perpetuate inaction. However, leading jurisdictions, leading companies and leading institutions are raising the bar. Focusing on what is happening at the leading edge is a means to stimulate advancements. If an engineering school wishes to be considered a leading institution in engineering design and in engineering education then it must embrace sustainability.

The paper presents examples of leading jurisdictions, leading companies and then leading engineering schools. The paper is not a comprehensive review of any of these three domains. The examples presented are just examples. The examples are not of perfection. They are largely examples of a work in progress.

\section{Jurisdictions}

Our Common Future put Sustainable Development on the world stage [6]. Globally Our Common Future has lead to the 1992 Earth Summit in Rio de Janeiro, the 2002 World Summit on Sustainable Development in 
Johannesburg and the preparations for EarthSummit 2012 (or Rio+20) to be held in Rio de Janeiro. The Earth Summit was an opportunity for the world to come together to commit to Sustainable Development. More than 178 countries adopted Agenda21 [7]. Agenda21 is a comprehensive plan and commitment detailed in 27 principles for local to global action. The World Summit on Sustainable Development lead to the Johannesburg Declaration including:

"we, the representatives of the peoples of the world, assembled at the World Summit on Sustainable Development in Johannesburg, South Africa, from 2 to 4 September 2002, reaffirm our commitment to sustainable development” [8]

These global meetings and global agreements can guide a direction but they in themselves rely on subsequent action. Individuals and individual entities need to follow.

The European Union has taken a significant step towards Changing Consumption Patterns (Agenda 21, Principle 8). The EU developed and implemented three Directives: End-of-Life Vehicle (ELV) Directive - 2000/53/EC, Waste Electrical and Electronic Equipment (WEEE) Directive - 2002/96/EC, Restriction Of the use of certain Hazardous Substances (RoHS) in electrical and electronic equipment Directive - 2002/95/EC [9]. Together they impact the design of every new car, cell phone, and washing machine sold throughout the EU. They require products to be recovered, reused, and/or recycled at the end of their normal life. These Directives are one of the driving forces behind the shift to Cradle-to-Cradle design thinking and responsibility from the historical Cradle-to-Grave. Cradle-to-Cradle thinking, introduced by William Stahel in the 1970s/1980s, requires the design of a product to plan for the next life of the item [10]. If the end fate of a laptop is disassembly for recovery and reuse of all components then the design at the outset will be very different. At the scale of the EU market, these Directives impact every engineering designer in the world. Initially, designers of cars and consumer electronics have to adapt. Eventually the advantages of cradle-to-cradle design will pervade all sectors.

Numerous communities/cities around the world have embraced sustainable principles. Sustainable Cities ${ }^{\mathrm{TM}}$ provides an excellent collection of case studies from around the world [11].

Hammerby Sjöstad, Stockholm, Sweden is an example of a community that has used sustainable principles in its rejuvenation. A closed loop, ecocycle model for waste, water and energy has been used for the sustainable infrastructure. The result is a community that produces $50 \%$ of its energy needs and uses only 100 Litres of water per capita per day [12].

\section{Companies}

Johnson \& Johnson $(\mathbf{J} \& \mathbf{J})$ is one example of a corporation committed to the concepts of sustainable development. However, J\&J was way ahead of the curve. J\&J established their Credo in 1943:

A commitment to their customers, employees, community, environment and shareholders [13].

They are a company that has grown from the simple Band-aid to most certainly an economic success (\$64 Billion in sales). It is their economic success, the quality of their products that is part of their ability to care for the environment and to matter in their communities. In Guelph, McNeil Consumer Healthcare (a J\&J company) is one of the best corporate citizens.

General Electric (GE) is also a large multinational economic success story. Global100 ranked GE as one of the top 100 "most sustainable companies in the world" [14]. GE's rating was based on a combination of commitments to human rights in addition to waste, water and carbon dioxide reductions all while increasing sales.

Interface carpets have received considerable attention for its sustainability transformation. In 1994, Mission Zero was developed as a 25 year plan to achieve sustainability. Mission Zero is a promise to eliminate all of their negative environmental impacts by the year 2020 [15]. By 2009, profits have doubled while net greenhouse gas emissions are down by $82 \%$. In the words of Ray Anderson (CEO), it is a better and more legitimate way to make a profit, one that is not at the expense of the environment or future generations [16]. The lens of sustainable design has unleashed a spirit of creativity and innovation that has made their products better than ever [16]. Their progress has benefited from a realigned business model. A business model in which revenue and profits grow with increased carpet life span rather than the traditional tie to carpet area sold.

The Body Shop is an enterprise that at its foundation was committed to sustainable development style principles. Anita Roddick (founder) believed that businesses have the power to do good. "That's why the Mission Statement of The Body Shop opened with the overriding commitment, 'To dedicate our business to the pursuit of social and environmental change.' The stores and products are used to help communicate human rights and environmental issues." [17] The Body Shop has grown from a first store in 1976 to over 2500 stores in 60 markets years. Fair trade has been 
part of their operations for over 20 years leading to income for 25000 people around the world [17].

\section{Engineering Education}

Progress towards sustainable development can only be achieved with the full participation of engineers. Professional engineering bodies have recognized this important role while accreditation bodies have moved to advance engineering education. For example, the Canadian Engineering Accreditation Board (CEAB) added a requirement that the "concepts of sustainable development must be an integral component of the engineering curriculum" for all engineering programs [18]. The Washington Accord requires all graduates to be capable of designing solutions that "meet specified needs with appropriate consideration for public health and safety, cultural, societal, and environmental considerations" and to "demonstrate knowledge of and need for sustainable development" [19]. The Canadian accreditation requirements have subsequently shifted to align more closely with the Washington Accord's phrasings [20].

The founders of Harvey Mudd College held that "technology divorced from humanity is worse than no technology at all" [21]. "Perhaps, as a colleague of mine recently suggested (P.F. Steinberg), the emergence of sustainability as a major driver of engineering education and research perhaps represents the mainstreaming on environmentalism. It would be nice to think that is uniformly true across all engineering disciplines, as well as across the practice of engineering and design. To the extent that it is not, as design and engineering educators we should also work energetically to make it so [22]." Sustainable design is not yet integral to all engineering programs.

Azapagic and colleagues conducted a worldwide survey on the state of engineering students' knowledge about sustainable development [23]. The survey involved 40 universities with over 3000 students completing the questionnaire from 2000 to 2002. The students were asked to self assess their knowledge in a range of sustainable development areas. They found that the base knowledge level was not satisfactory and that significant gaps prevailed.

Huntzinger and colleagues reviewed sustainable thinking within a number of engineering schools (mostly US schools) [24]. They reflected on the level of integration ranging from, in their terms, ignorance (none), to bolted on, to built in and ultimately to redesign. They argue that active learning modes and a redesign approach to engineering education is necessary to achieve success in sustainable design education.
Holmberg and colleagues draw from their experiences at three European universities to identify five areas in which a strong foundation will increase likelihood of success in sustainable development education [25]. The five areas are: legitimacy (is focusing on sustainable development legitimate), commitment by university administration, responsibility is spread throughout the university, skilled teachers with sustainable development experience, and an effective structure within the university.

There are schools that seem to have the necessary ingredients and are energetically making progress. In some schools, the progress is focused on one or two courses. There are also schools in which the progress has been more comprehensive.

The University of Leeds has embedded sustainable design within their second year design course [26]. In a project based learning mode the students are required to imagine a larger scale system that is much more sustainable and then to develop a design for a component of that system that is needed for the vision to be realized.

At Northwestern, the $1^{\text {st }}$ and $2^{\text {nd }}$ year design courses have introduced cradle-to-cradle thinking [27]. The teaching approach has used a combination of readings, prototyping and student reflections. Students reached a level of knowing and understanding of the cradle-to-cradle concept. However, they did not consistently translate the concept into their designs in the absence of direct encouragement by a client.

Washington State University have integrated the EU Directives (ELV, RoHS and WEEE) into their Systems Design program [28]. In their second year, students are required to design an aircraft subsystem while tracking compliance with the Directives.

The University of Guelph integrates sustainable design within their core second year design course for all students. Students are required quantify their design's social value, its raw material cost and its recycled value post use. Following demonstration and testing, students have a maximum of ten minutes to completely disassemble their design.

Rensselaer Polytechnic Institute uses a reverse engineering strategy in their capstone course [29]. Students develop a sustainability score for comparison of four typical consumer products.

Adams et al. [30] discuss the value of using grand engineering challenges as a basis for sustainable development education. They used different disaster cases as a basis to compare the sustainable design response of students at 2 US universities and 1 Chinese institution.

At the United States Coast Guard Academy, the campus is used as setting for sustainable 
development education [31]. Students learned that the technology element (changing light bulbs) is the easy part in comparison to the essential behaviour elements.

TU Delft began pursuit of sustainable development within its engineering curriculum in 1994 [32]. They have subsequently developed an optional sustainable development graduation track available to students across disciplines. Students are able receive a sustainable development certificate by completing a colloquium, a number of courses from an elective list and a graduation project with sustainable development as an integral element.

Rowan University has a significant sustainable component in every program. Their strategy is to have modules of sustainability in what appears to be $25-50 \%$ of their curriculum. "Rowan engineering program is focused on developing a more globally aware engineer dedicated to the development of sustainable designs to promote sustainable societies [33]"

Carnegie Mellon has introduced a series of mini courses available to senior undergraduates and graduate students across all engineering disciplines [34].

In 2004, Michigan Technical University started offering an interdisciplinary, graduate certificate in sustainability [35].

University of Calgary together with OLADE (Latin America Energy Organization) offers a multidisciplinary program in Sustainable Energy [36]. Participating students are from engineering, architecture, economics and business, science and law.

University of Kentucky has proposed a design for sustainability curriculum that spans first year to doctorate degrees for the next generation of design and manufacturing engineers. [37]

\section{Reflection}

Sustainable Development is a challenge before us.

It is easy to blame our political leaders for the challenges the world faces. However, our global political leaders have taken the most important first step. They lead the introduction of Sustainable Development to the world's agenda. They have publically and globally endorsed it and reinforced that endorsement. They have taken some second steps through their regulatory powers. Many municipalities have taken up the challenge.

It is easy to blame corporations for the challenges the world faces. However, leading companies have embraced sustainable development practices and philosophies. Some companies have historically been there. Some have been listening to the world and have adapted. They have demonstrated that the vision of sustainability is viable.

Engineers have a significant role to play. Many engineering schools around the world have taken the first steps and some schools have jumped in with both feet. Our students are ready to be engineers of the future as illustrated in the banner shown in Figure 1: Sustainability Starts Here. Guelph engineering students created the banner for our building's front entrance.

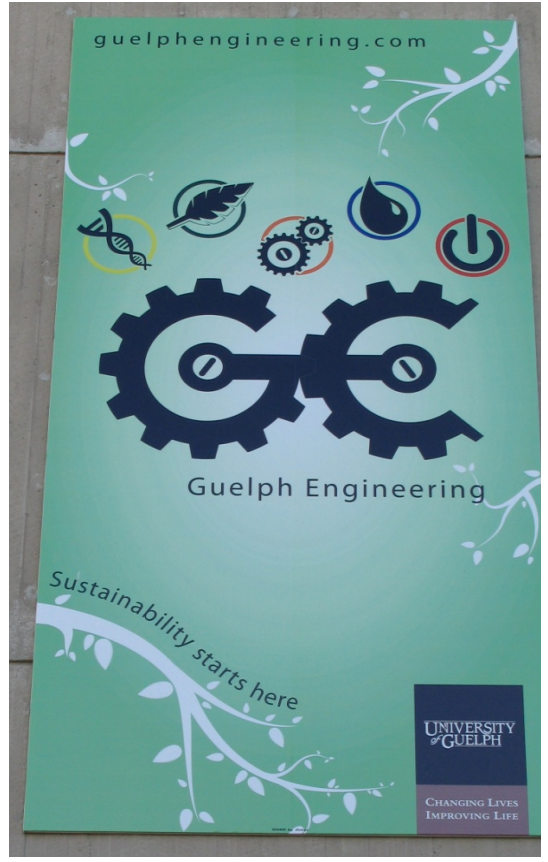

Figure 1: Sustainability Starts Here

It is time for all engineering schools to choose to graduate engineers for tomorrow's world. Our great, grandchildren will thank us.

\section{References}

[1] World Commission on Environment and Development, Our Common Future, Oxford University Press, Oxford, p8, 1987.

[2] United Nations, Population Division of the Department of Economic and Social Affairs of the United Nations Secretariat, World Population Prospects: The 2008 Revision, http://esa.un.org/unpp, May 2010,

[3] United Nations AIDS Program, 2006 Global Report, available unaids.org/en/KnowledgeCentre/HIVData/EpiUpdate/E piUpdArchive/2006/default.asp

[4] SustainAbility, www.sustainability.com

[5] Vellone J., Engineering Sustainability, Engineering Dimensions, v25, no6, Nov/Dec 2004.

[6] World Commission on Environment and Development, Our Common Future, Oxford University Press, Oxford, 400p, 1987. 
[7] United Nations, www.un.org/esa/dsd/agenda21/; accessed May 2010.

[8] United Nations, www.un.org/esa/sustdev/ documents/WSSD POI PD/English/POI PD.htm; accessed May 2010.

[9] End-of-Life Vehicle (ELV) Directive - 2000/53/EC, Waste Electrical and Electronic Equipment (WEEE) Directive - 2002/96/EC, Restriction Of the use of certain Hazardous Substances (RoHS) in electrical and electronic equipment Directive - 2002/95/EC, available at eur-lex.europa.eu/en/index.htm

[10] The Product-Life Institute, www.product-life.org

[11] Sustainable Cities, sustainablecities.dk, accessed May 2010.

[12] Sweden, Environment: Clear goals shape Swedish environmental policy, www.sweden.se/eng/ Home/Quick-facts/Facts/Environment-Clear-goals-shap e-Swedish-environmental-policy/, September 22, 2008, accessed July 2009.

[13] Johnson \& Johnson, www.jnj.com/our_company/our_credo history/index.ht $\underline{\mathrm{m}}$.

[14] Global100, www.global100.org/index.php, accessed April 2010.

[15] Interface, www.interfaceglobal.com/sustainability/ourjourney.aspx, accessed November 2010.

[16] TED, $\quad$ www.ted.com/talks/lang/eng/ ray anderson on the business logic of sustainability html

[17] The Body Shop, www.thebodyshop.com/ en/ ww/ services/aboutus company.aspx, Accessed May 2010.

[18] Canadian Council of Professional Engineers, Canadian Engineering Accreditation Board, Accreditation Criteria and Procedures 1999, 1999.

[19] International Engineering Alliance, Washington Accord, Washington Accord Rules and Procedures, www.washingtonaccord.org, updated 2007-08-15, 2007

[20] Engineers Canada, Canadian Engineering Accreditation Board, Accreditation Criteria and Procedures 2008, www.engineerscanada.ca, September, 2008.

[21] Harvey Mudd College, www.hmc.edu/academicsclinicresearch/ourcurriculum/ integrativeexperience.html, accessed May 2010.

[22] Dym C.L., Sustainability: Affirming Engineering Values, Mudd Design Workshop VII, "Sustaining Sustainable Design," Harvey Mudd College in Claremont, California, 28-30 May 2009.

[23] Azapagic A., S. Perdan and D. Shallcross, How much do engineering students know about sustainable development? The findings of an international survey and possible implications for the engineering curriculum, European Journal of Engineering Education, 30(1):1-19, 2005.

[24] D.N. Huntzinger, M.J. Hutchins, J.S. Gierke, and J.W. Sutherland, Enabling Sustainable Thinking in Undergraduate Engineering Education, International Journal of Engineering Education, 23:218-230, 2007.

[25] J. Holmberg, M. Svanström, D.-J. Peet, K. Mulder, D. Ferrer-Balas, and J. Segalàs, Embedding sustainability in higher education through interaction with lecturers: Case studies from three European technical universities, European Journal of Engineering Education, 33:271-282, 2008.

[26] A. McKay and D. Raffo, Project-based Learning: a Case Study in Sustainable Design, International Journal of Engineering Education, 23:1096-1115, 2007.

[27] Gerber E., McKenna A., Hirsch P., Yarnoff C., Learning to Waste - Wasting to Learn: Changing the Enviromental Footprint of Teaching Design, Mudd Design Workshop VII, "Sustaining Sustainable Design," Harvey Mudd College in Claremont, California, 28-30 May 2009.

[28] Ameta G., Panchal J.H., Pezeshki C., A CollectiveLearning Approach to Sustainable Design Education, Mudd Design Workshop VII, "Sustaining Sustainable Design," Harvey Mudd College in Claremont, California, 28-30 May 2009.

[29] Morris J., Steiner M., Quantifying Sustainability through Reverse Engineering: A Multi-Disciplinary Senior Capstone Experience, Mudd Design Workshop VII, "Sustaining Sustainable Design," Harvey Mudd College in Claremont, California, 28-30 May 2009.

[30] Adams R.S., Beltz N., Mann L., Wilson D., Formulating Cross-Disciplinary Problems Involving Design for Sustainability: Empirical Explorations Across Three Global Contexts, Mudd Design Workshop VII, "Sustaining Sustainable Design," Harvey Mudd College in Claremont, California, 28-30 May 2009.

[31] Fleischmann C., Thompson S., Zitzman L, Garcia L., Gurr N., Sustainability: A Campus Initiative, Mudd Design Workshop VII, "Sustaining Sustainable Design," Harvey Mudd College in Claremont, California, 28-30 May 2009.

[32] de Werk G., L.M. Kamp, Evaluation of the sustainable development graduation track at Delft University of Technology, European Journal of Engineering Education, 33:221-229, 2008.

[33] Jahan K., Mehta Y., Sustainability Across the Curriculum, International Journal of Engineering Education, 23(2): 209-217, 2007.

[34] C.I. Davidson, C.T. Hendrickson, and H.S. Matthews, Sustainable Engineering: A Sequence of Courses at Carnegie Mellon, International Journal of Engineering Education, 23:287-293, 2007.

[35] Hokanson D.R., Phillips L.D., Michelcic J.R., Educating Engineers in the Sustainable Futures Model with a Global Perspective: Education, Research and Diversity Initiatives, Int'1 J. Engng Ed, 23(2):254-265., 2007.

[36] Hurtado O., Hunte C., Educating Engineers in Sustainable Energy Development: an Interdisciplinary Approach, IJEE, 23(2):266-275, 2007.

[37] Jawahir I.S., Rouch K.E., Dillon O.W., Holloway L., Hall A., Design for Sustainability (DFS): New Challenges in Developing and Implementing a Curriculum for the Next Generation Design and Manufacturing Engineers, IJEE, 23(6): 1053-1064, 2007 